ISSN: 2302-8556

\title{
Pengaruh Ukuran Perusahaan, Profitabilitas, Koneksi Politik dan Pengungkapan Corporate Social Responsibility Pada Tax Avoidance
}

\author{
Pande Putu Biantari Darmayanti ${ }^{1}$ \\ Ni Ketut Lely Aryani Merkusiwati ${ }^{2}$ \\ ${ }^{1,2}$ Fakultas Ekonomi dan Bisnis Universitas Udayana (Unud), Bali, Indonesia \\ e-mail: biantaripande@gmail.com
}

\begin{abstract}
ABSTRAK
Variabel yang diteliti dalam penelitian ini adalah ukuran perusahaan, profitablitas, koneksi politik dan pengungkapan corporate social responsibility (CSR). Tujuan penelitian ini adalah untuk memperoleh hasil empiris mengenai pengaruh ukuran perusahaan, profitablitas, koneksi politik dan pengungkapan corporate social responsibility (CSR) pada tax avoidance. Penelitian ini dilakukan di Bursa Efek Indonesia (BEI). Jumlah sampel yang diambil sebanyak 38 perusahaan manufaktur dengan metode nonprobability sampling khususnya purposive sampling. Periode penelitian adalah tahun 2014-2017. Pengumpulan data dilakukan dengan teknik observasi non-participant. Teknik analisis data yang digunakan adalah regresi linier berganda. Hasil penelitian ini menunjukkan bahwa ukuran perusahaan, koneksi politik dan pengungkapan corporate social responsibility tidak berpengaruh pada tax avoidance sedangkan profitabilitas berpengaruh negatif pada tax avoidance. Besarnya laba yang diperoleh perusahaan sangat berpengaruh pada tindakan perusahaan untuk melakukan praktik tax avoidance.
\end{abstract}

Kata kunci: Tax avoidance, ukuran perusahaan, profitabilitas, koneksi politik, pengungkapan corporate social responsibility

\begin{abstract}
The variables examined in this study are company size, profitability, political connections and disclosure of corporate social responsibility (CSR). The purpose of this study is to obtain empirical results regarding the effect of company size, profitability, political connections and disclosure of corporate social responsibility (CSR) on tax avoidance. This research was conducted on the Indonesia Stock Exchange (IDX). The number of samples taken as many as 38 manufacturing companies with nonprobability sampling method, especially purposive sampling. The research period is 2014-2017. Data collection is done by non-participant observation techniques. The data analysis technique used is multiple linear regression. The results of this study indicate that company size, political connections and disclosure of corporate social responsibility have no effect on tax avoidance while profitability has a negative effect on tax avoidance. The amount of profit obtained by the company is very influential on the company's actions to practice tax avoidance.

Keywords: Tax avoidance, company size, profitability, political connections, disclosure of corporate social responsibility
\end{abstract}

\section{PENDAHULUAN}

Salah satu sumber pendapatan Negara terbesar adalah Pajak. Pajak dapat mendukung kegiatan pembangunan nasional suatu Negara. Oleh karena itu, pajak 
menjadi fenomena yang penting dan menarik untuk dibahas. Hal ini dikarenakan pajak selalu mengalami perkembangan terutama di Indonesia sehingga diperlukan informasi-informasi dan studi-studi terbaru mengenai kondisi pajak dari waktu ke waktu. Pemerintah terus berupaya untuk memperbaiki sistem perpajakan menjadi lebih baik dalam rangka mewujudkan pembangunan nasional dan menyejahterakan seluruh masyarakat Indonesia. Tentunya hal ini tidaklah mudah karena pembangunan tersebut membutuhkan dana yang tidak sedikit. Maka dari itu, pemerintah membuat kebijakan-kebijakan mengenai pajak sehingga penerimaan pajak semakin besar dan pembangunan nasional pun bisa terlaksana dengan baik.

Tabel 1 menunjukkan bahwa persentase realisasi penerimaan pajak terhadap target penerimaan pajak pada tahun 2014 sampai dengan tahun 2017 berfluktuatif. Terjadi penurunan penerimaan pajak yang cukup signifikan pada tahun 2016 sehingga berdampak pada tahun selanjutnya yaitu penurunan target yang ditetapkan. Namun, meskipun target pada tahun 2017 telah diturunkan dari tahun sebelumnya realisasi penerimaan pajak pada tahun tersebut masih belum mencapai target. Hal ini menjadi pertanyaan faktor apa yang memengaruhi penerimaan pajak yang belum mencapai target tersebut. Ada banyak faktor yang memengaruhi tercapainya target penerimaan pajak tersebut misalnya keadaan perekonomian yang masih lesu, fiskus yang belum secara maksimal memberikan pelayanan terhadap wajib pajak atau dari wajib pajak tersebut yang belum memiliki kesadaran untuk membayar pajak. Adapun target dan realisasi penerimaan pajak tahun 2014-2017 dapat dilihat pada Tabel 1 berikut. 
Tabel 1.

Target dan Realisasi Penerimaan Pajak Tahun 2014-2017 (Dalam Triliun Rupiah)

\begin{tabular}{cccc}
\hline Tahun & Target & Realisasi & Persentase \\
\hline 2014 & $1.246,1$ & $1.146,9$ & 92,0 \\
2015 & $1.489,3$ & $1.240,4$ & 83,3 \\
2016 & $1.539,2$ & $1.094,2$ & 71,7 \\
2017 & $1.283,57$ & $1.151,1$ & 89,6 \\
\hline
\end{tabular}

Sumber: Data diolah, 2018

Terdapat perbedaan kepentingan antara pemerintah dan wajib pajak. Bagi pemerintah, pajak sangat diperlukan untuk pembiayaan kegiatan pembangunan nasional dan pengeluaran Negara lainnya. Di lain pihak, wajib pajak ingin membayar pajak sekecil-kecilnya karena dengan membayar pajak maka kemampuan ekonomis mereka akan berkurang. Pajak bagi perusahaan merupakan beban yang harus ditanggung, pajak dapat mengurangi laba perusahaan sehingga perusahaan mencari berbagai cara untuk mengurangi beban pajak tersebut (Wijayanti dan Lely, 2017).

Perbedaan kepentingan ini dapat menyebabkan terjadinya kendala dalam penerimaan pajak. Kendala tersebut salah satunya adalah penghindaran pajak. Penghindaran pajak umumnya dapat dibedakan menjadi penggelapan pajak (tax evasion) dan penghindaran pajak (tax avoidance). Penggelapan pajak yaitu tindakan yang dilakukan wajib pajak terkait dengan penggunaan cara-cara yang melanggar hukum untuk mengurangi atau menghilangkan beban pajak, sedangkan penghindaran pajak (tax avoidance) dilakukan sesuai peraturan yang berlaku dengan cara memanfaatkan celah-celah yang terdapat dalam peraturan perpajakan yang ada untuk menghindari pembayaran pajak.

Fenomena penghindaran pajak (tax avoidance) yang terjadi salah satunya dilakukan oleh perusahaan asal Swedia yaitu IKEA. IKEA adalah sebuah 
perusahaan yang bergerak di sektor peralatan rumah tangga. Namun, diketahui perusahaan ini melakukan upaya penghindaran pajak dengan nilai lebih dari \$1 miliar dalam kurun waktu lima tahun yaitu tahun 2009 sampai tahun 2014. IKEA memindahkan labanya dari negara-negara dengan tarif pajak tinggi ke anak perusahaannya yang berlokasi negara-negara dengan tarif pajak rendah. Selain itu, IKEA juga membebankan biaya royalti dari satu perusahaan ke perusahaan lain dalam lingkup kepemilikan yang sama dengan tujuan meminimalisir beban pajak mereka. Pada tahun 2014, IKEA diduga melakukan penghindaran pajak senilai \$39 juta di Jerman, \$26 juta di Prancis, dan \$13 juta di Inggris. Hal ini menyebabkan Uni Eropa mengalami kerugian puluhan miliar dollar per tahunnya (forumpajak.org).

Selain itu, ada beberapa kasus tax avoidance yang dilakukan di Indonesia. Direktorat Jenderal Pajak Kementerian Keuangan (DJP Kemenkeu) menyatakan sebanyak 2.000 perusahaan multinasional yang beroperasi di Indonesia tidak membayar Pajak Penghasilan (PPh) Badan Pasal 25 dan Pasal 29 karena alasan merugi. Perusahaan-perusahaan tersebut menggunakan tiga modus utama yaitu transfer pricing, memanfaatkan insentif pajak (tax holiday), dan mengganti nama perusahaan agar dapat terhindar dari kewajiban menyetor pajak di Indonesia (liputan6.com).

Terdapat faktor-faktor yang memengaruhi perusahaan dalam melakukan tax avoidance antara lain ukuran perusahaan, koneksi politik, pengungkapan CSR dan faktor lainnya. Faktor-faktor yang diteliti dalam penelitian ini terkait dengan tax avoidance adalah ukuran perusahaan, profitablitas, koneksi politik dan 
pengungkapan CSR. Alasan digunakannya faktor-faktor tersebut sebagai variabel dalam penelitian ini karena dalam penelitian-penelitian terdahulu mengenai tax avoidance memberikan hasil yang tidak konsisten pada variabel ukuran perusahaan, profitabilitas, koneksi politik, dan pengungkapan CSR.

Ukuran perusahaan dapat diukur salah satunya dengan jumlah aset yang dimiliki. Perusahaan yang memiliki aset besar akan cenderung menghasilkan laba yang besar dan akan mengakibatkan pajak yang harus dibayarkan juga besar. Hal ini mendorong perusahaan untuk memanfaatkan sumber daya manusia yang dimilikinya untuk melakukan manajemen laba. Semakin besar ukuran perusahaan, maka transaksi yang dilakukan semakin kompleks sehingga memungkinkan perusahaan untuk memanfaatkan celah-celah atau kelemahan yang ada pada ketentuan perundang-undangan untuk melakukan tindakan tax avoidance dari setiap transaksi (Merslythalia dan Lasmana, 2016). Hasil penelitian yang dilakukan oleh Dewinta dan Setiawan (2016) serta Putri dan Putra (2017) menyebutkan bahwa ukuran perusahaan berpengaruh positif dan signifikan pada tax avoidance, sedangkan menurut hasil penelitian Merslythalia dan Lasmana (2016) serta Annisa (2017) ukuran perusahaan tidak berpengaruh pada tax avoidance.

Profitabilitas adalah kemampuan perusahaan dalam menghasilkan laba. Perusahaan besar biasanya akan menghasilkan laba yang tinggi sehingga akan memengaruhi profitabilitas. Profitabilitas perusahaan yang tinggi akan mendorong manajemen untuk menghasilkan pajak optimal dengan meminimalkan beban pajaknya, sehingga perusahaan cenderung melakukan tax avoidance (Nugrahitha, 
2018). Hasil penelitian oleh Putri dan Putra (2017) serta Utari dan Supadmi (2017) menyebutkan bahwa profitabilitas berpengaruh negatif pada tax avoidance, sedangkan menurut penelitian yang dilakukan oleh Dewinta dan Setiawan (2016) menunjukkan hasil bahwa profitabilitas berpengaruh positif pada tax avoidance.

Perusahaan biasanya memiliki banyak koneksi di berbagai bidang untuk keberlangsungan usahanya terutama untuk meningkatkan laba. Tidak hanya dalam bidang usaha atau bisnis namun juga politik. Perusahaan dengan koneksi politik akan lebih berani melakukan upaya minimalisasi pajaknya karena risiko untuk diperiksa akan lebih rendah bahkan tidak akan mengalami pemeriksaan oleh badan pemeriksa pajak (Mulyani dkk., 2014). Hal ini menyebabkan perusahaan cenderung melakukan tax avoidance. Koneksi politik disebut berpengaruh positif pada tax avoidance, hal ini sesuai dengan penelitian yang dilakukan oleh Utari dan Supadmi (2017). Namun, penelitian yang dilakukan oleh Lestari dan Asri (2017) memperoleh hasil bahwa koneksi politik tidak berpengaruh pada tax avoidance.

Menurut World Bank Group tanggung jawab sosial perusahaan atau dikenal dengan istilah Corporate Social Responsibility (CSR) disebut sebagai komitmen bisnis berkelanjutan yang dilakukan perusahaan sehingga berpengaruh pada lingkungan sekitar dan masyarakat umum. CSR berpengaruh dalam meningkatkan kualitas sarana prasarana dan keberlangsungan hidup masyarakat. Artinya, dengan adanya CSR ini, perusahaan memberikan kontribusi dalam meningkatkan kesejahteraan masyarakat secara umum. Hal ini memiliki tujuan 
yang sama dengan pajak yaitu mewujudkan pembangunan nasional dan meningkatkan kesejahteraan seluruh masyarakat Indonesia.

Perusahaan yang berperilaku tax avoidance dianggap tidak bertanggung jawab secara sosial (Hidayati dan Fidiana, 2017). Pengungkapan CSR dapat memengaruhi tax avoidance dengan jumlah pengungkapan CSR yang dilakukan perusahaan. Semakin banyak pengungkapan yang dilakukan perusahaan maka semakin rendah tingkat tax avoidance yang dilakukan perusahaan. Penelitian yang dilakukan oleh Hidayati dan Fidiana (2017) menyatakan bahwa pengungkapan CSR memberikan pengaruh positif pada tax avoidance. Namun, penelitian yang dilakukan oleh Lionita dan Kusbandiyah (2017) memberikan hasil bahwa pengungkapan CSR tidak berpengaruh pada tax avoidance.

Menurut Machfoedz (1994) dalam Dewinta dan Setiawan (2016) menyatakan bahwa ukuran perusahaan merupakan suatu skala yang dapat mengelompokkan perusahaan menjadi perusahaan besar dan kecil menurut berbagai cara. Cara tersebut antara lain dapat melalui total aset perusahaan yang dimiliki, nilai pasar saham, rata-rata tingkat penjualan, jumlah penjualan, dan lainlain. Ukuran perusahaan dibagi menjadi tiga klasifikasi, yaitu Perusahaan Besar (Large Firm), Perusahaan Menengah (Medium Firm) dan Perusahaan Kecil (Small Firm).

Semakin besar aset yang dimiliki perusahaan maka modal yang ditanam juga semakin besar. Menurut Putri (2017), semakin besar ukuran perusahaan biasanya memengaruhi informasi yang tersedia untuk investor dalam mengambil keputusan sehubungan dengan investasi saham yang ditanamkan dalam 
perusahaan tersebut semakin banyak. Oleh karena itu, kualitas laporan keuangan harus reliable, terbebas dari manajemen laba karena dapat mengaburkan informasi yang tersedia. Terutama yang berkaitan dengan minimalisasi laba untuk meminimalkan pendapatan kena pajak, sehingga pembayaran pajak juga kecil.

Profitabilitas merupakan salah satu pengukuran bagi kinerja suatu perusahaan. Profitabilitas suatu perusahaan menunjukkan kemampuan suatu perusahaan dalam menghasilkan laba selama periode tertentu pada tingkat penjualan, asset dan modal saham tertentu (Dewinta dan Setiawan , 2016). Rasio profitabilitas menjadi bentuk penilaian terhadap kinerja manajemen dalam mengelola kekayaan perusahaan yang ditunjukkan oleh laba yang dihasilkan (Putri, 2017).

Salah satu rasio profitabilitas adalah Return On Assets (ROA). ROA adalah rasio yang menggambarkan sejauh mana kemampuan aset-aset yang dimiliki perusahaan dalam menghasilkan laba. ROA digunakan karena dapat memberikan pengukuran yang memadai atas keseluruhan efektifitas perusahaan dan ROA juga dapat memperhitungkan profitabilitas. ROA merupakan pengukur keuntungan bersih yang diperoleh dari seberapa besar perusahaan menggunakan asset (Dewinta dan Setiawan , 2016).

Perusahaan yang memiliki koneksi politik ialah perusahaan yang dengan cara-cara tertentu mempunyai ikatan secara politik atau mengusahakan adanya kedekatan dengan politisi atau pemerintah (Mulyani, 2014). Hubungan istimewa yang dimaksudkan antara pemilik perusahaan dengan pemerintah adalah pemilik perusahaan merupakan tokoh politik yang terkemuka yang dimana merupakan 
anggota dewan baik itu di pemerintahaan pusat maupun daerah ataupun sebagai anggota partai politik (Wicaksono, 2017). Selain itu, koneksi politik juga dapat dilihat dari kepemilikan saham pemerintah.

Dengan adanya hubungan istimewa tersebut yang menciptakan koneksi politik, maka perusahaan dapat memanfaatkan peluang untuk melakukan tax avoidance. Dengan koneksi politik, baik pihak perusahaan ataupun pihak politisi dapat menghalangi aktifitas pajak seperti pemeriksaan pajak dan aktifitas lainnya.

Ukuran perusahaan biasanya memengaruhi perusahaan untuk melakukan tindakan tax avoidance. Perusahaan yang memiliki aset besar akan cenderung lebih mampu dan lebih stabil untuk menghasilkan laba dibandingkan perusahaan dengan aset kecil. Laba yang besar dan stabil akan berdampak pada beban pajak yang besar. Hal ini menyebabkan perusahaan yang dengan aset besar akan memaksimalkan sumber daya manusia yang dimiliki untuk melakukan perencanaan pajak dengan tujuan untuk meminimalisasi pembayaran pajak (Putra dan Lely, 2016).

Semakin besar ukuran perusahaan maka semakin rumit pola organisasi yang dimiliki perusahaan. Hal ini dapat mendorong perusahaan untuk memanajemen laba dalam hal ini bertujuan untuk mengurangi beban pajak yang harus dibayarkan. Hal ini dapat dilakukan dengan cara melakukan transaksitransaksi tertentu antar perusahaan yang dapat mengurangi beban pajak.

Penelitian yang dilakukan oleh Dewinta dan Setiawan (2016) serta Putri dan Putra (2017) menyebutkan bahwa ukuran perusahaan berpengaruh positif dan signifikan pada tax avoidance, sedangkan menurut hasil penelitian Merslythalia 
dan Lasmana (2016) serta Annisa (2017) ukuran perusahaan tidak berpengaruh pada tax avoidance. Berdasarkan uraian di atas hipotesis yang dirumuskan dalam penelitian ini yaitu sebagai berikut.

$\mathrm{H}_{1}$ : Ukuran perusahaan berpengaruh positif pada tax avoidance.

Rasio profitabilitas digunakan dalam menilai kinerja manajemen dalam pengelolaan asset perusahaan. Hal ini ditunjukkan dengan seberapa besar laba yang dihasilkan perusahaan. Pengukuran rasio profitabilitas ini dapat menggunakan Return on Assets (ROA). ROA adalah suatu indikator yang mencerminkan performa keuangan perusahaan, semakin tingginya nilai ROA yang mampu diraih oleh perusahaan maka performa keuangan dan pengelolaan aset perusahaan tersebut dapat dikategorikan baik (Saputra, 2015).

Semakin tinggi nilai ROA maka kinerja perusahaan dinilai semakin baik dalam menghasilkan laba (Dewi dan Noviari, 2017). Ketika laba yang diperoleh membesar, maka jumlah pajak penghasilan akan meningkat sesuai dengan peningkatan laba perusahaan sehingga kecenderungan untuk melakukan tax avoidance yang dilakukan oleh perusahaan semakin besar (Dewinta dan Setiawan, 2016). Hasil penelitian oleh Putri dan Putra (2017) serta Utari dan Supadmi (2017) menyebutkan bahwa profitabilitas berpengaruh negatif pada tax avoidance, sedangkan menurut penelitian yang dilakukan oleh Dewinta dan Setiawan (2016) menunjukkan hasil bahwa profitabilitas berpengaruh positif pada tax avoidance. Berdasarkan uraian di atas hipotesis yang dirumuskan dalam penelitian ini yaitu sebagai berikut.

$\mathrm{H}_{2}$ : Profitabilitas berpengaruh positif pada tax avoidance. 
Koneksi politik sering dimanfaatkan untuk mengambil manfaat atas pajak menggunakan kedekatan dengan pemerintah untuk memperoleh perlakuan istimewa dari pemerintah. Koneksi politik yang dilakukan oleh perusahaan baik itu BUMN maupun BUMS adalah untuk melakukan pendekatan dengan pemerintah untuk menghindari pemeriksaan pajak, pengajuan pengurangan denda pajak maupun tindakan lain yang tergolong tax evasion atau tax agreesiveness (Wicaksono, 2017). Hubungan antara perusahaan sebagai pemilik dengan pemerintah sebagai pemegang saham dominan dimanfaatkan oleh pihak perusahaan untuk melakukan tindakan tax avoidance karena perusahaan yang berkoneksi politik diindikasikan adanya perlakuan yang istimewa dari pemerintah sehingga mengakibatkan menurunnya transparansi pada laporan keuangan perusahaan (Windaswari dan Lely, 2018).

Koneksi politik disebut berpengaruh positif pada tax avoidance, hal ini sesuai dengan penelitian yang dilakukan oleh Utari dan Supadmi (2017). Namun, penelitian yang dilakukan oleh Lestari dan Asri (2017) memperoleh hasil bahwa koneksi politik tidak berpengaruh pada tax avoidance. Berdasarkan uraian di atas hipotesis yang dirumuskan dalam penelitian ini yaitu sebagai berikut.

$\mathrm{H}_{3}$ : Koneksi Politik berpengaruh positif pada tax avoidance.

Perusahaan memanfaatkan celah-celah tertentu untuk melakukan tindakan tax avoidance. Salah satunya dapat melalui Corporate Social Responsibility (CSR). Program CSR yang dilakukan oleh perusahaan misalnya melaksanakan program CSR antara lain program beasiswa, program kesehatan untuk masyarakat, pelestarian lingkungan, dukungan terhadap Usaha Mikro, Kecil dan 
Menengah (UMKM), dan lain-lain. Jadi untuk melakukan tindakan tax avoidance tersebut mereka mengungkapkan bahwa telah melaksanakan program CSR sehingga dapat meningkatkan citra baik perusahaan di mata investor dan masyarakat. Artinya, perusahaan yang melakukan tanggung jawab sosial sematamata hanya menggunakan tindakan yang socially responsible untuk memperoleh penilaian yang positif agar perusahaan dapat menutupi tindakan mereka yang socially irresponsible seperti tax avoidance (Hidayati dan Firdiana, 2017).

Penelitian yang dilakukan oleh Hidayati dan Fidiana (2017), pengungkapan CSR memberikan pengaruh positif pada tax avoidance. Namun, penelitian yang dilakukan oleh Lionita dan Kusbandiyah (2017) memberikan hasil bahwa pengungkapan CSR tidak berpengaruh pada tax avoidance. Berdasarkan uraian di atas hipotesis yang dirumuskan dalam penelitian ini yaitu sebagai berikut.

$\mathrm{H}_{4}$ : Pengungkapan corporate social responsibility berpengaruh positif pada tax avoidance.

\section{METODE PENELITIAN}

Lokasi penelitian ini adalah Bursa Efek Indonesia (BEI). Alasan pemilihan lokasi di BEI karena BEI adalah pihak yang menyelenggarakan dan menyediakan sarana untuk memertemukan penawaran jual dan beli efek pihak-pihak lain dengan tujuan memerdagangkan efek diantara mereka. Oleh karena itu, BEI menyediakan informasi laporan keuangan perusahaan dengan mengakses situs resmi BEI yaitu www.idx.co.id. 
Variabel independen dalam penelitian ini adalah Ukuran Perusahaan $\left(\mathrm{X}_{1}\right)$, Profitabilitas $\left(\mathrm{X}_{2}\right)$, Koneksi Politik $\left(\mathrm{X}_{3}\right)$, dan Pengungkapan Corporate Social Responsibility $\left(\mathrm{X}_{4}\right)$ sedangkan untuk variabel dependennya adalah Tax Avoidance (Y).

Rumus yang digunakan dalam pengukuran variabel ini adalah sebagai berikut.

Size $=$ Ln $($ Total Asset $)$

ROA digunakan karena dapat memberikan pengukuran yang memadai atas keseluruhan efektifitas perusahaan dan dapat memerhitungkan profitabilitas. ROA dapat diukur dengan rumus berikut.

$$
\text { ROA }=\frac{\text { Laba }(\text { Rugi)Setelah Pajak }}{\text { Total Aset }} \times 100 \%
$$

Pengukuran variabel koneksi politik dalam penelitian ini adalah dengan variabel dummy. Pengukuran variabel ini mengacu pada penelitian yang dilakukan oleh Windaswari dan Lely (2018) yaitu apabila terdapat kepemilikan saham pemerintah (BUMN) dalam perusahaan akan diberikan nilai 1 dan akan diberikan nilai 0 jika tidak.

Rumus untuk menghitung Corporate Social Responsibility Disclosure Index (CSRDI) adalah sebagai berikut.

$$
\operatorname{CSRDI}_{\mathrm{j}}=\frac{\sum \mathrm{X}_{\mathrm{ij}}}{\mathrm{n}_{\mathrm{j}}}
$$

Keterangan:

$\mathrm{CSRDI}_{\mathrm{j}}$ : Indeks luas pengungkapan tanggung jawab sosial dan lingkungan perusahaan $\mathrm{j}$.

$\sum \mathrm{X}_{\mathrm{ij}} \quad$ : nilai 1 jika item i diungkapkan; nilai 0 jika item i tidak diungkapkan. $\mathrm{n}_{\mathrm{j}} \quad$ : jumlah item untuk perusahan $\mathrm{j}, \mathrm{n}_{\mathrm{j}} \leq 91$. 
Penelitian ini menggunakan perhitungan yang telah dilakukan oleh Hidayati dan Fidiana (2017) dengan menggunakan proksi Current ETR, yaitu sebagai berikut.

$$
\text { Current ETR }=\frac{\text { Pajak Kini }}{\text { Total Laba Sebelum Pajak }}
$$

Populasi dalam penelitian ini adalah perusahaan sektor manufaktur yang terdaftar di Bursa Efek Indonesia selama 2014-2017. Sektor manufaktur dipilih karena sektor manufaktur memiliki peran yang cukup besar dalam penerimaan pajak negara. Metode penentuan sampel yang digunakan dalam penelitian ini adalah purposive sampling.

Teknik analisis data yang digunakan dalam penelitian ini adalah Teknik analisis regresi linier berganda. Analisis regresi linier berganda adalah hubungan secara linear antara dua atau lebih variabel independen $\left(\mathrm{X}_{1}, \mathrm{X}_{2}, \ldots \mathrm{Xn}\right)$ dengan variabel dependen (Y). Analisis ini untuk mengetahui arah hubungan antara variabel independen dengan variabel dependen apakah masing-masing variabel independen berhubungan positif atau negatif dan untuk memprediksi nilai dari variabel dependen apabila nilai variabel independen mengalami kenaikan atau penurunan. Model analisis regresi berganda dalam penelitian ini dinyatakan sebagai berikut.

$$
Y=\alpha+\beta_{1} X_{1}+\beta_{2} X_{2}+\beta_{3} X_{3}+\beta_{4} X_{4}+e
$$

Keterangan:

$\begin{array}{ll}\mathrm{Y} & : \text { Tax Avoidance } \\ \alpha & : \text { Konstanta } \\ \beta_{1}, \beta_{2}, \beta_{3}, \beta_{4} & : \text { Koefisien Regresi dari masing-masing variabel } \\ \mathrm{X}_{1} & : \text { Ukuran Perusahaan } \\ \mathrm{X}_{2} & : \text { Profitabilitas } \\ \mathrm{X}_{3} & : \text { Koneksi Politik }\end{array}$


$\mathrm{X}_{4} \quad$ : Pengungkapan Corporate Social Responsibility

e : error

\section{HASIL DAN PEMBAHASAN}

Statistik deskriptif memberikan gambaran mengenai data yang tersaji sehingga dapat lebih mudah dipahami oleh pembaca. Data-data tersebut antara lain informasi mengenai karakteristik variabel-variabel penelitian yang terdiri atas jumlah pengamatan, nilai minimum, nilai maksimum, nilai rata-rata, dan standar deviasi dapat dilihat dalam Tabel 2 berikut.

Tabel 2.

Hasil Analisis Statistik Deskriptif

\begin{tabular}{lccccc}
\hline Variabel & $\begin{array}{c}\text { Jumlah } \\
\text { Sampel }\end{array}$ & $\begin{array}{c}\text { Nilai } \\
\text { Minimum }\end{array}$ & $\begin{array}{c}\text { Nilai } \\
\text { Maksimum }\end{array}$ & Nilai Rata-Rata & $\begin{array}{c}\text { Standar } \\
\text { Deviasi }\end{array}$ \\
\hline Tax Avoidance & 152 & 0,0658 & 0.7277 & 0.2629 & 0.0801 \\
Ukuran & 152 & 25,6195 & 33.3202 & 28.8807 & 1.7027 \\
Perusahaan & & & & & \\
Profitabilitas & 152 & 0,0018 & 0.5267 & 0.0959 & 0.0754 \\
Koneksi Politik & 152 & 0 & 1 & 0.11 & 0.308 \\
Pengungkapan & 152 & 0,1428 & 0.2308 & 0.1865 & 0.0254 \\
CSR & & & & &
\end{tabular}

Sumber: Data diolah, 2018

Perusahaan yang memiliki nilai minimum untuk variabel tax avoidance adalah PT Mandom Indonesia Tbk sebesar 0,0658 artinya tingkat tax avoidance dalam perusahaan ini cenderung tinggi, sedangkan perusahaan yang memiliki nilai maksimum pada variabel tax avoidance adalah PT Jembo Cable Company Tbk sebesar 0.7277 yang artinya tingkat tax avoidance dalam perusahaan ini cenderung rendah. Nilai rata-rata dari variabel tax avoidance yang diproksikan dengan Current ETR adalah sebesar 0.2629 dengan standar deviasi sebesar 0.0801 .

Perusahaan yang memiliki nilai minimum untuk variabel ini adalah PT Lionmesh Prima Tbk sebesar 25,6195 artinya ukuran perusahaan ini tergolong 
kecil. Perusahaan yang memiliki nilai maksimum pada variabel ini adalah PT Astra International Tbk sebesar 33.3202 artinya perusahaan ini tergolong perusahaan dengan ukuran besar. Nilai rata-rata dari variabel ukuran perusahaan yang diproksikan dengan logaritma natural total aset adalah 28.8807 dengan standar deviasi sebesar 1.7027.

Perusahaan yang memiliki nilai minimum untuk variabel profitabilitas adalah PT Jembo Cable Company Tbk sebesar 0,0018 artinya kinerja perusahaan dalam menghasilkan laba cenderung kurang baik sedangkan perusahaan yang memiliki nilai maksimum untuk variabel ini adalah PT Multi Bintang Indonesia Tbk sebesar 0.5267 artinya kinerja perusahaan dalam menghasilkan laba cenderung baik. Nilai rata-rata dari variabel profitabilitas yang diproksikan dengan Return On Assets (ROA) adalah 0.0959 dengan standar deviasi sebesar 0.0754 .

Nilai rata-rata dari variabel koneksi politik yang diproksikan dengan kepemilikan saham pemerintah adalah sebesar 0.11 dengan standar deviasi sebesar 0.308. Nilai rata-rata sebesar 0,11 yang lebih kecil dari 0,5 menunjukkan bahwa koneksi politik dengan kode 1, yaitu kepemilikan saham pemerintah lebih sedikit muncul dari 152 sampel penelitian yang diteliti. Jumlah sampel yang sahamnya dimiliki oleh pemerintah adalah sebanyak 16 sampel dan sampel yang sahamnya tidak dimiliki oleh pemerintah sebanyak 136 sampel.

Perusahaan yang memiliki nilai minimum untuk variabel pengungkapan CSR adalah PT Sekar Bumi Tbk sebesar 0,1428 artinya pengungkapan CSR yang dilakukan perusahaan ini cenderung sedikit. Perusahaan yang memiliki nilai 
maksimum untuk varibel ini adalah PT Siantar Top Tbk sebesar 0.2308 pengungkapan CSR yang dilakukan perusahaan ini cenderung lebih banyak. Nilai rata-rata dari variabel pengungkapan CSR yang diproksikan dengan CSRDI adalah sebesar 0.1865 dengan standar deviasi sebesar 0.0254 .

Analisis regresi linier berganda dalam penelitian ini menggunakan tingkat signifikansi 5\%. Hasil dari analisis regresi linier berganda dapat dilihat pada Tabel 3 berikut.

Tabel 3.

Hasil Analisis Regresi Linier Berganda

\begin{tabular}{lccccc}
\hline \multicolumn{1}{c}{ Variabel } & \multicolumn{2}{c}{$\begin{array}{c}\text { Unstandardized } \\
\text { Coefficient }\end{array}$} & $\begin{array}{c}\text { Standardized } \\
\text { Coefficient }\end{array}$ & $\mathrm{t}$ & Sig \\
& $\mathrm{B}$ & Std. Error & Beta & & \\
\hline Constant & 0,483 & 0,106 & & 4,546 & 0,000 \\
Ukuran Perusahaan & $-0,005$ & 0,004 & $-0,107$ & $-1,250$ & 0,213 \\
Profitabilitas & $-0,293$ & 0,087 & $-0,276$ & $-3,387$ & 0,001 \\
Koneksi Politik & $-0,020$ & 0,020 & $-0,077$ & $-0,977$ & 0,330 \\
Pengungkapan CSR & $-0,240$ & 0,280 & $-0,076$ & $-0,855$ & 0,394 \\
$F_{\text {hitung }}$ & $: 4,627$ & & & & \\
Sig. F & $: 0,002$ & & & & \\
Adjusted $R$ Square & $: 0,088$ & & & &
\end{tabular}

Berdasarkan Tabel 3, persamaan regresi dalam penelitian ini dinyatakan sebagai berikut.

$$
\begin{aligned}
& Y=\alpha+\beta_{1} X_{1}+\beta_{2} X_{2}+\beta_{3} X_{3}+\beta_{4} X_{4}+\mathrm{e} \ldots \ldots \ldots \ldots \ldots \ldots \ldots \ldots \ldots \\
& Y=0,483-0,005 X_{1}-0,293 X_{2}-0,020 X_{3}-0,240 X_{4}+e
\end{aligned}
$$

Nilai konstanta $(\alpha)$ yang bernilai 0,483 menunjukkan bahwa apabila nilai semua variabel independen yaitu ukuran perusahaan, profitabilitas, koneksi politik dan pengungkapan CSR dalam keadaan konstan, maka nilai dari tax avoidance adalah sebesar 0,483 . Nilai koefisien regresi $\left(\beta_{1}\right)$ pada variabel ukuran perusahaan $\left(\mathrm{X}_{1}\right)$ sebesar -0,005 menunjukkan bahwa apabila ukuran perusahaan meningkat 1 satuan, maka tax avoidance akan menurun sebesar 0,005 satuan dengan asumsi 
variabel lainnya konstan. Nilai koefisien regresi $\left(\beta_{2}\right)$ pada variabel profitabilitas $\left(\mathrm{X}_{2}\right)$ sebesar -0,293 menunjukkan bahwa apabila profitabilitas meningkat 1 satuan, maka tax avoidance akan menurun sebesar 0,293 satuan dengan asumsi variabel lainnya konstan.

Nilai koefisien regresi $\left(\beta_{3}\right)$ pada variabel koneksi politik $\left(X_{3}\right)$ sebesar 0,020 menunjukkan bahwa apabila koneksi politik meningkat 1 satuan, maka tax avoidance akan menurun sebesar 0,020 satuan dengan asumsi variabel lainnya konstan. Nilai koefisien regresi $\left(\beta_{4}\right)$ pada variabel pengungkapan CSR $\left(\mathrm{X}_{4}\right)$ sebesar -0,240 menunjukkan bahwa apabila pengungkapan CSR meningkat 1 satuan, maka tax avoidance akan menurun sebesar 0,240 satuan dengan asumsi variabel lainnya konstan.

Pada uji kelayakan model (uji F), model regresi dikatakan layak apabila hasil uji $\mathrm{F}$ menghasilkan signifikansi atau p-value $<0,05$. Berdasarkan Tabel 3 diketahui nilai signifikansi dari uji statistik $\mathrm{F}$ adalah 0,002, maka model regresi dinyatakan layak (fit) untuk digunakan. Artinya variabel-variabel independen yaitu ukuran perusahaan $\left(\mathrm{X}_{1}\right)$, profitabilitas $\left(\mathrm{X}_{2}\right)$, koneksi politik $\left(\mathrm{X}_{3}\right)$ dan pengungkapan CSR $\left(\mathrm{X}_{4}\right)$ secara simultan (serempak) berpengaruh signifikan terhadap variabel dependen yaitu tax avoidance $(\mathrm{Y})$.

Koefisien determinasi merupakan pengukuran yang digunakan untuk mengetahui kemampuan model dalam menerangkan variasi variabel dependen. Nilai koefisien determinasi yang digunakan dalam penelitian ini adalah nilai adjusted $R$ Square untuk menerangkan pengaruh variabel yang jumlahnya lebih dari dua variabel independen. Penelitian ini menggunakan 4 (empat) variabel 
independen oleh karena itu nilai yang digunakan adalah nilai adjusted $R$ Square. Nilai adjusted $R$ Square yang diperoleh adalah sebesar 0,088, artinya 8,8\% tingkat tax avoidance yang terjadi pada perusahaan manufaktur berdasarkan penelitian ini dipengaruhi oleh ukuran perusahaan, profitabilitas, koneksi politik dan pengungkapan CSR. Sisanya sebesar 91,2\% dipengaruhi oleh variabel lain yang tidak termasuk dalam penelitian ini.

Hipotesis pertama $\left(\mathrm{H}_{1}\right)$ menyatakan ukuran perusahaan berpengaruh positif pada tax avoidance. Hasil analisis pada Tabel 3 menunjukkan nilai signifikansi dari variabel ukuran perusahaan $\left(\mathrm{X}_{1}\right)$ sebesar 0,213 lebih besar dari $\alpha$ yaitu 0,05 , maka $\mathrm{H}_{1}$ ditolak. Artinya, ukuran perusahaan tidak berpengaruh pada tax avoidance.

Hipotesis kedua $\left(\mathrm{H}_{2}\right)$ menyatakan profitabilitas berpengaruh positif pada tax avoidance. Hasil analisis pada Tabel 4.4 menunjukkan nilai signifikansi dari variabel profitabilitas $\left(\mathrm{X}_{2}\right)$ sebesar 0,001 lebih kecil dari 0,05, maka $\mathrm{H}_{2}$ diterima. Artinya, profitabilitas berpengaruh pada tax avoidance. Koefisien regresi untuk variabel profitabilitas $\left(X_{2}\right)$ bernilai negatif yaitu sebesar $-0,293$. Hal ini artinya profitabilitas berpengaruh negatif pada tax avoidance.

Hipotesis ketiga $\left(\mathrm{H}_{3}\right)$ menyatakan koneksi politik berpengaruh positif pada tax avoidance. Hasil analisis pada Tabel 3 menunjukkan nilai signifikansi dari variabel koneksi politik $\left(\mathrm{X}_{3}\right)$ sebesar 0,330 lebih besar dari $\alpha$ yaitu 0,05 , maka $\mathrm{H}_{3}$ ditolak. Artinya, koneksi politik tidak berpengaruh pada tax avoidance.

Hipotesis keempat $\left(\mathrm{H}_{4}\right)$ menyatakan pengungkapan corporate social responsibility berpengaruh positif pada tax avoidance. Hasil analisis pada Tabel 
4.4 menunjukkan nilai signifikansi dari variabel pengungkapan CSR $\left(\mathrm{X}_{4}\right)$ sebesar 0,394 lebih besar dari $\alpha$ yaitu 0,05, maka $\mathrm{H}_{4}$ ditolak. Artinya, pengungkapan CSR tidak berpengaruh pada tax avoidance.

Berdasarkan hasil analisis data di atas, pengujian ini tidak mampu membuktikan bahwa ukuran perusahaan berpengaruh pada tax avoidance. Hal ini sejalan dengan penelitian yang dilakukan oleh Merslythalia dan Lasmana (2016) serta Annisa (2017) yang membuktikan bahwa ukuran perusahaan tidak berpengaruh pada tax avoidance.

Besar kecilnya suatu perusahaan yang diukur melalui aset yang dimiliki tidak memengaruhi keputusan perusahaan untuk melakukan tindakan tax avoidance. Selain itu, perusahaan tidak ingin mengambil risiko atas tindakan tax avoidance yang mungkin dilakukan karena hal tersebut akan berdampak pada citra perusahaan. Jadi perusahaan dengan ukuran yang besar maupun kecil samasama patuh terhadap peraturan perpajakan yang berlaku sehingga akan berdampak positif untuk perusahaan di waktu yang akan datang.

Berdasarkan hasil analisis data di atas, profitabilitas berpengaruh negatif pada tax avoidance. Hal ini sejalan dengan penelitian yang dilakukan oleh Putri dan Putra (2017) serta Utari dan Supadmi (2017) yang membuktikan bahwa profitabilitas berpengaruh negatif pada tax avoidance. Profitabilitas yang diukur dengan Return On Assets (ROA) yaitu rasio antara laba bersih dengan total aset perusahaan memberikan gambaran mengenai efektivitas penggunaan aset dalam kegiatan operasional untuk menghasilkan laba berpengaruh pada tindakan tax 
avoidance. Artinya besarnya laba yang diperoleh perusahaan sangat berpengaruh pada tindakan perusahaan untuk melakukan praktik tax avoidance.

Koefisien regresi untuk variabel profitabilitas menunjukkan arah pengaruh negatif terhadap variabel tax avoidance. Artinya, semakin tinggi nilai profitabilitas maka kecenderungan perusahaan untuk melakukan tindakan tax avoidance semakin rendah ditunjukkan oleh nilai Current ETR yang tinggi. Sebaliknya, apabila nilai profitabilitas rendah maka kecenderungan perusahaan untuk melakukan tindakan tax avoidance semakin tinggi ditunjukkan oleh nilai Current ETR yang rendah (mendekati nol).

Manajemen memertimbangkan tersedianya segala informasi dari nilai profitabilitas. Nilai ROA yang tinggi menunjukkan bahwa performa perusahaan semakin bagus sehingga akan memengaruhi tindakan yang diambil oleh perusahaan. Mereka juga memertimbangkan implikasi tindakan yang diambil secara implisit dan eksplisit termasuk tindakan untuk melakukan praktik tax avoidance. Apabila terjadi kesalahan akibat tindakan yang kurang tepat akan memengaruhi citra perusahaan.

Perusahaan dengan nilai profitabilitas yang tinggi diasumsikan tidak melakukan tindakan tax avoidance karena pertimbangan citra perusahaan akan menjadi buruk apabila perusahaan melakukan tindakan tersebut. Namun, perusahaan dengan nilai profitabilitas yang kecil diasumsikan melakukan tindakan tax avoidance karena perusahaan dengan profitabilitas rendah pada umumnya mengalami kesulitan keuangan (financial difficulty) sehingga cenderung akan melakukan ketidakpatuhan pajak (Arianandini dan Ramantha, 2018). 
Berdasarkan hasil analisis data di atas, pengujian ini tidak mampu membuktikan bahwa koneksi politik berpengaruh pada tax avoidance. Hal ini sejalan dengan penelitian yang dilakukan oleh Lestari dan Asri (2017) yang membuktikan bahwa koneksi politik tidak berpengaruh pada tax avoidance.

Koneksi politik tidak berpengaruh karena perusahaan yang sahamnya sebagian besar dimiliki pemerintah ditetapkan sebagai wajib pajak yang rendah resikonya sesuai dengan Peraturan Menteri Keuangan Nomor 71/PMK.03/2010 (Lestari dan Asri, 2017). PMK ini memberikan gambaran bahwa perusahaan yang mayoritas pemegang sahamnya adalah pemerintah tidak melakukan tindakan tax avoidance. Hubungan yang dimiliki perusahaan dengan pemerintah membuat perusahaan untuk berhati-hati dalam mengambil keputusan agar terhindar dari risiko terkait sanksi perpajakan. Hal ini yang memotivasi perusahaan sehingga patuh terhadap peraturan perpajakan yang berlaku. Tidak hanya kepada pemerintah, perusahan juga menjaga citranya agar tetap dipercaya oleh investor, konsumen dan masyarakat untuk keberlangsungan usahanya sehingga tidak akan mengambil keputusan untuk melakukan tindakan tax avoidance yang manfaatnya hanya dirasakan dalam jangka pendek.

Berdasarkan hasil analisis data di atas, pengujian ini tidak mampu membuktikan bahwa pengungkapan corporate social responsibility berpengaruh pada tax avoidance. Hal ini sejalan dengan penelitian yang dilakukan oleh Lionita dan Kusbandiyah (2017) yang memperoleh hasil bahwa pengungkapan corporate social responsibility tidak berpengaruh pada tax avoidance. 
Jumlah item yang diungkapkan dalam pengungkapan CSR tidak memengaruhi perusahaan untuk melakukan tindakan tax avoidance. Hal ini karena perusahaan memiliki kesadaran akan tanggung jawab sosial yang harus dilakukan untuk keberlangsungan usahanya. Pengungkapan CSR yang dilakukan perusahaan diharapkan dapat berdampak baik bagi masyarakat dan perusahaan itu sendiri.

\section{SIMPULAN}

Variabel ukuran perusahaan tidak berpengaruh pada tax avoidance. Besar kecilnya suatu perusahaan yang diukur melalui logaritma natural total aset yang dimiliki tidak memengaruhi keputusan perusahaan untuk melakukan tindakan tax avoidance.

Variabel profitabilitas berpengaruh negatif pada tax avoidance. Semakin tinggi nilai profitabilitas maka kecenderungan perusahaan untuk melakukan tindakan tax avoidance semakin rendah. Sebaliknya, apabila nilai profitabilitas rendah maka kecenderungan perusahaan untuk melakukan tindakan tax avoidance semakin tinggi.

Variabel koneksi politik tidak berpengaruh pada tax avoidance. Koneksi politik tidak berpengaruh karena perusahaan yang sahamnya sebagian besar dimiliki pemerintah ditetapkan sebagai wajib pajak yang rendah resikonya sesuai dengan Peraturan Menteri Keuangan Nomor 71/PMK.03/2010. 
Variabel pengungkapan corporate social responsibility tidak berpengaruh pada tax avoidance. Jumlah item yang diungkapkan dalam pengungkapan CSR tidak memengaruhi perusahaan untuk melakukan tindakan tax avoidance.

Bagi perusahaan diharapkan dapat mengelola perusahaannya dengan baik dan tidak mengambil keputusan untuk melakukan tax avoidance karena hal tersebut merupakan tindakan yang kurang baik yang dapat merugikan negara, masyarakat serta perusahaan itu sendiri. Keputusan yang diambil haruslah tepat sehingga terhindar dari risiko yang akan merugikan perusahaan apabila diketahui melakukan tindakan tax avoidance.

Hasil uji koefisien determinasi dalam penelitian menunjukkan $8,8 \%$ tingkat tax avoidance yang terjadi pada perusahaan manufaktur dipengaruhi oleh ukuran perusahaan, profitabilitas, koneksi politik dan pengungkapan corporate social responsibility. Sisanya sebesar 91,2\% dipengaruhi oleh variabel lain yang tidak termasuk dalam penelitian ini. Oleh karena itu, bagi peneliti selanjutnya diharapkan agar menambahkan variabel lainnya yang mungkin memengaruhi tax avoidance misalnya terkait corporate governance yaitu komite audit, kualitas audit, komisaris independen, dan lain-lain.

Variabel ukuran perusahaan sebaiknya digunakan sebagai variabel kontrol, karena ukuran perusahaan memengaruhi jumlah sumber daya yang dimiliki perusahaan. Perbedaan sumber daya memengaruhi perbedaan laba yang diperoleh dan beban pajak yang dikenakan untuk perusahaan.

Pengukuran variabel pengungkapan CSR sebaiknya dilakukan dengan menghitung jumlah item yang diungkapan saja apabila penelitian yang dilakukan 
untuk tahun-tahun sebelum tahun 2018. Hal ini karena indikator GRI versi G4 pada tahun 2017 ke atas belum diterapkan melainkan hanya digunakan sebagai pedoman. Pengukuran variabel tax avoidance dapat menggunakan proksi lain selain current ETR, misalnya cash ETR atau book tax different.

\section{REFERENSI}

Aditya Nugrahitha, I. M., \& Suprasto, H. B. (2018). Pengaruh Profitabilitas, Leverage, Corporate Governance, dan Karakter Eksekutif pada Tax Avoidance. E-Jurnal Akuntansi Universitas Udayana, 22(36), 2016-2039.

Annisa. (2017). Pengaruh Return On Asset, Leverage, Ukuran Perusahaan dan Koneksi Politik Terhadap Penghindaran Pajak. JOM Fekon, Vol. 4(No. 1), 115.

Anouar, D. (2017). The Determinants of Tax Avoidance within Corporate Groups: Evidence from Moroccan Groups. International Journal of Economics, Finance and Management Sciences, 5(1), 57.

Avi-yonah, R. (2017). International Tax Avoidance - Introduction. Accounting, Economics, and Law: A Convivium., 7-11.

Aziza, K. (2016). Pengaruh Penghindaran Pajak Terhadap Biaya Hutang dengan Kepemilikan Institusional Sebagai Variabel Moderasi Pada Perusahaan Manufaktur Yang Terdaftar Di Bursa Efek Indonesia Periode 2013-2015. Historia Social, 1(86), 71-90.

Aziza, N. (2014). Anteseden Pengungkapan Lingkungan dan Pengaruhnya Terhadap Image Perusahaan (Studi Empiris pada Perusahaan Manufaktur di Indonesia). Jurnal Fairness, 4, 1-21.

Dewi, N. L. P. P., \& Noviari, N. (2017). Pengaruh Ukuran Perusahaan, Leverage, Profitabilitas, dan Corporate Social Responsibility Terhadap Penghindaran Pajak (Tax Avoidance). E-Jurnal Akuntansi Universitas Udayana, 21(1), 830-859.

Dewinta, I. A. R., \& Setiawan, P. E. (2016). Pengaruh Ukuran Perusahaan, Umur Perusahaan, Profitabilitas, Leverage, Dan Pertumbuhan Penjualan Terhadap Tax Avoidance. E-Jurnal Akuntansi Universitas Udayana, 14(3), 15841613. 
Fellegi, M. (2013). Tax Evasion or Tax Optimization : is there any Narrow Path between the Two? "Club of Economics in Miskolc" TMP, 9(2), 35-40.

Ghozali, I. (2016). Aplikasi Analisis Multivariete Dengan Program IBM SPSS 23, edisi 8. Semarang: Badan Penerbit Universitas Diponegoro.

Hidayati, N., \& Fidiana. (2017). Pengaruh corporate Social Responsibility dan Good Corporate Governance terhadap Penghindaran Pajak. Jurnal Ilmu Dan Riset Akuntansi, 6(3), 1052-1070.

Huda, M. K., Nugraheni, N., \& Kamarudin, K. (2017). The Problem of Transfer Pricing in Indonesia Taxation System. International Journal of Economics and Financial Issues, 7(4), 139-143.

Jamei, R. (2017). Tax Avoidance and Corporate Governance Mechanisms: Evidence from Tehran Stock Exchange. International Journal of Economics and Financial Issues, 7(4), 638-644.

Kementerian Keuangan Republik Indonesia. (2018). www.kemenkeu.go.id. Diakses 30 Agustus 2018.

Kim, J. H., \& Im, C. C. (2017). The Study On The Effect And Determinants Of Small - And Medium-Sized Entities Conducting Tax Avoidance. The Journal of Applied Business Research, 33(2), 375-391.

Lestari, G. A. W., \& Putri, I. G. A. M. A. D. (2017). Pengaruh Corporate Governance, Koneksi Politik, dan Leverage terhadap Penghindaran Pajak. EJurnal Akuntansi Universitas Udayana, 18, 2028-2054.

Lionita, H. A., \& Kusbandiyah, A. (2017). Pengaruh Corporate Social Responsibility, Profitabilitas, Leverage dan Komisaris Independen terhadap Praktik Penghindaran Pajak pada Perusahaan yang Terdaftar di BEI. Kompartemen, $X V(1), 1-11$.

Masripah, Diyanty, V., \& Fitriasari, D. (2015). Controlling Shareholder and Tax Avoidance: Governance, Family Ownership and Corporate. International Research Journal of Business Studies, VIII(3), 167-180.

Merslythalia, D. R., \& Lasmana, M. S. (2016). Komisaris Independen , Dan Kepemilikan Institusional Terhadap Tax Avoidance the Effect of Executive Competency, the Firm Size, the Independent Commisioner and the Institusional Ownership Towards Tax Avoidance. Jurnal Ilmiah Akuntansi Dan Bisnis, 11(2), 117-124.

Mulyani, S., Darminto, \& N.P, M. G. W. E. (2014). Pengaruh Karakteristik Perusahaan, Koneksi Politik dan Reformasi Perpajakan Terhadap 
Penghindaran Pajak (Studi Pada Perusahaan Manufaktur Yang Terdaftar di Bursa Efek Tahun 2008-2012). Jurnal Bisnis Manajemen Dan Ekonomi, 2(1), 1-9.

Park, S. J., Women, S., \& Korea, S. (2016). Through The International Transfer Pricing. The Journal of Applied Business Research, 32(3), 917-935.

Pradipta, D. H., \& Supriyadi. (2016). Pengaruh Corporate Social Responsibility (CSR), Profitabilitas, Leverage, dan Komisaris Independen Terhadap Praktik Penghindaran Pajak. Kompartemen Jurnal Ilmiah Akuntansi, XV(1), 1-11.

Purwantini, H. (2017). Minimizing Tax Avoidance by Using Conservatism Accounting Through Book Tax Differences ( Case Study in Indonesia ). Research in Business and Social Science IJRBS, Special Issue, ISSN: $2147-$ $4478,6(5), 55-67$.

Putra, I. G. L. N. D. C., \& Merkusiwati, N. K. L. A. (2016). Pengaruh Komisaris Independen, Leverage, Size Dan Capital Intensity Ratio Pada Tax Avoidance. E-Jurnal Akuntansi Universitas Udayana, 17(1), 690-714.

Putri, V. R., \& Putra, B. I. (2017). Pengaruh Leverage, Profitability, Ukuran Perusahaan dan Proporsi Kepemilikan Institusional Terhadap Tax Avoidance. Jurnal Ekonomi Manajemen Sumber Daya, 19(1), 1-11.

Reskino, \& Imam, I. C. (2016). Kajian Empiris Beban Pajak Tangguhan dan Kepemilikan Institusional Terhadap Manajemen Laba. Jurnal InFestasi, 12(1), 55-65.

Salihu, I. A., Normala, S., Obid, S., \& Annuar, H. A. (2013). Measures of Corporate Tax Avoidance: Empirical Evidence From an Emerging Economy. International Journal of Business and Society, 14(3), 412-427.

Saputra, M. F., Rifa, D., \& Rahmawati, N. (2015). Pengaruh Corporate Governance, Profitabilitas dan Karakter Eksekutif Terhadap Tax Avoidance. Jurnal Akuntansi \& Auditing Indonesia, 19(1), 1-12.

Sari, D. K., \& Rossieta, H. (2017). Tax Avoidance , Related Party Transactions , Corporate Governance and The Corporate Cash Dividend Policy. Journal of Indonesian Economy and Business, 32(3), 190-208.

Subagiastra, Komang, I Putu Edy Arizona, dan I. N. K. A. M. (2016). Governance Terhadap Penghindaran Pajak. Jurnal Ilimah Akuntansi, 1(2), 167-193.

Sugiyono. (2017). Metode Penelitian Bisnis. Bandung: CV Alfabeta. 
Sunarsih, U., \& Oktaviani, K. (2016). Good Corporate Governance in Manufacturing Companies Tax Avoidance. Etikonomi, 15(2), 85-96.

Susanti, M. (2017). Corporate Social Responsibility , Size and Tax Avoidance. International Journal of Economic Perspectives, 11(1), 1639-1650.

Thai Ha; Phan Gia Quyen. (2017). The relationship between state ownership and tax avoidance level: empirical evidence from Vietnamese firms. Asian Economic and Social Society, 7(December), 0-12.

Utari, N. K. Y., \& Supadmi, N. L. (2017). Pengaruh Corporate Governance, Profitabilitas Dan Koneksi Politik Pada Tax Avoidance. E-Jurnal Akuntansi Universitas Udayana, 18, 2202-2230.

Wicaksono, A. P. N. (2017). Koneksi Politik dan Aggresivitas Pajak: Fenomena di Indonesia. Akuntabilitas, 10(1), 167-180.

Wijayanti, P., \& Rismawati, S. (2017). The Impact Of Financial Condition And Corporate Social Responsibility To The Aggressiveness Of Company. International Journal of Organizational, 9(April 2017), 244-258.

Wijayanti, Y. C., \& Merkusiwati, N. K. L. A. (2017). Pengaruh Proporsi Komisaris Independen, Kepemilikan Institusional, Leverage, dan Ukuran Perusahaan Pada Penghindaran Pajak. E-Jurnal Akuntansi Universitas Udayana, 20(1), 699-728.

Windaswari, K. A., \& Merkusiwati, N. K. L. A. (2018). Pengaruh Koneksi Politik , Capital Intensity, Profitabilitas, Leverage dan Ukuran Perusahaan Pada Agresivitas Pajak. E-Jurnal Akuntansi Universitas Udayana, 23, 1980-2008.

Yogiswari, N. K. K., \& Ramantha, I. W. (2017). Pengaruh Likuiditas dan Corporate Social Responsibility pada Agresivitas Pajak dengan Corporate Governance Sebagai Variabel Pemoderasi. E-Jurnal Akuntansi Universitas Udayana, 21, 730-759. 